\title{
The time to lead
}

ACRL needs you

$\mathbf{W}$ ould you like to seek office in an ACRL section? Would you like to nominate anyone else for one of these positions? If the answer is yes, here is what you need to do.

\section{ACRL section officers}

Candidates for vice-chair/chair-elect of ACRL sections are selected by the Nominating Committee of each section. If you would like to nominate someone or be nominated for vicechair of an ACRL section, contact the chair of the Nominating Committee for the appropriate section prior to the ALA Annual Conference in San Francisco. Other section officers, including secretary and member-at-large, may also be uncler consideration for this term of office. which will begin in the summer of 1998.

\section{Section nominating committee chairs} Afro-American Studies Librarian. Rochelle R. Ballard, University of Central Florida Library, P.O. Box 162666, Orlando, FL 32816; ballard@pegasus.cc.ucf.edu

Anthropology and Sociology. James Williams, University of Illinois Library, 1408 West Gregory Drive, Rm 111, Urbana, IL 61801-3607; jamesww@uxl.cso.uiuc.edu.

Arts. Christine A. Whittington, University of Maine, 5729 Fogler Lilorary, Orono, ME 044695729; christin@maine.maine.edu.

Asian, African, and Middle Eastern. To be announced. Contact the current chair, Brenda E. Bickett. bicketth@gunet.georgetown.edu.

College Libraries. Lynn K. Chmelir, Northup Library. Linfield College, McMinnville, OR 97128-6894; lchmelir@linfield.edu.

Community and Junior College Libraries. Susan Maltese, Oakton Comm. College, 1600 E. Golf, Des Plaines, IL 60016; susanm@oakton.edu.
English and American Literature. Mádeline A. Copp, Occidental College Library, 1600 Campus Road, Los Angeles, CA 90041-3384; mcopp@oxy.edu

Education and Behavioral Sciences. Charles 13. Thurston, University of Texas at San Antonio Library, 6900 N Loop 1604 West, San Antonio, TX 78249: thurston@lonestar.utsa.edu.

Extended Campus Library Services. Maryhelen W. Jones, Central Michigan University, Charles V. Park Library, Mount Pleasant. MI 48859; maryhelen.jones@cmich.edu.

Instruction. Bonnie Osif. Pennsylvania State University, 325 Hammond, University Park, PA 16802; bao@psulias.psu.edu.

Law and Political Science. To be announced. Contact the current section chair, Carolina J Tibbetts, cjt@vms.cis.pitt.edu.

Rare Books and Manuscripts. Elizabeth L. Johnson, Incliana University, Lilly Library Bloomington, IN 47405; johnson1@indiana.edu

Science and Technology. Alison Scott Ricker, Oberlin College, Kettering Hall Science Library, 130 West Lorain, Oberlin, OH 44074-1083; pasricker@oberlin.edu.

Slavic and East European. Alàn P. Pollard, University of Michigan, Hatcher Graduate Library North, Ann Arbor, MI 48109-1205.

University Libraries. Karen $\mathrm{S}$. Seibert, University of Texas, P.O. Box 7458, Austin, TX 78713; kss@mail.utexas.edu.

Western European Specialists. Heidi Lou Hutchinson. University of California-Riverside, Rivera Library, P.O. Box 5900, Riverside, CA 92517-5900; heidi@citrus.ucr.edu.

Women's Studies. Mila C. Su. Penn State University, Fiche Library, Altoona Campus, Altoona, PA 16601; MCS@PSULIAS.PSU.EDU. 


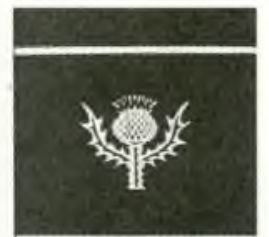

\section{The evolution of}

\section{a classic.}

You've trusted Britannica for years, and as the information needs of schools and libraries have changed, so have we. Britannica Onlinethe first encyclopedia on the Intemet - is already used by more than three million students at hundreds of the most prestigious universities in the world. And now it's available to answer your questions in your library, anytime. It's fast, it's convenient, and because it's Britannica, it's the right answer!

For a free two-week preview of Britannica Online 97, call 1-800-621-3900 or visit http://www.eb.com today.

The 1997 version features: - Almost 1000 new graphics

- Over 5000 related Internet links - Thumbnails of images in the text - Updated content • and more!

\section{Britannica}

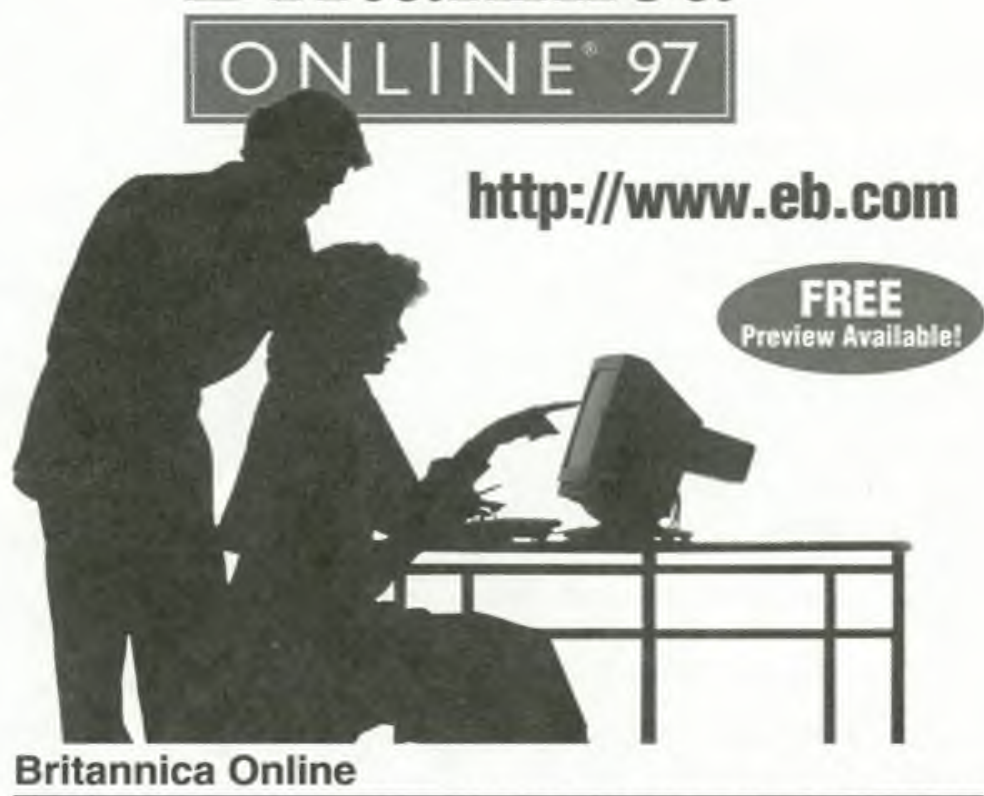

MICROPADIA

Ready

Reference
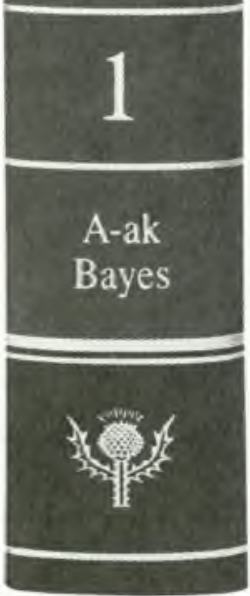

From the editors of ENCYCLOPÆDIA BRITANNICA: 